\title{
Analisis Pengaruh Limbah Cair Terhadap Kualitas Perairan Pantai Kelapa Lima Kota Kupang
}

\author{
Etty M. M Sabuin ${ }^{\text {a*, Fonny Risamasu }}{ }^{\text {a }}$, Frans Kiaduan ${ }^{\text {a }}$ \\ a Program Studi Ilmu Lingkungan, Program Pascasarjana, Universitas Nusa Cendana, Jl. Adi Sucipto Penfui, Kota \\ Kupang, Provinsi Nusa Tenggara Timur-Indonesia, 85001. \\ *Email: etysabuin@yahoo.co.id
}

Diterima (received) 18 Januari 2019; disetujui (accepted) 29 Juli 2019; tersedia secara online (available online) 1 Agustus 2019

\begin{abstract}
Marine life and natural scenery - in the category of nautical tourism - are the potentials of the Kelapa Lima, Kupang beach. However, there are problems that; construction progress, residentials and bussines activities nearby coast of Kelapa Lima, Kupang, indicated that there are contamination by wastewater into the waters of this beach. Then, this issue is adjusted to the standards Environment Minister Regulation number 51 of 2014 and in 2013 number 115 on the sea water quality standard. The method used is the equation written by Sumiotomo and Nerow (1970) in the Minister of Environment No. 115 of 2003. The formula that is used to calculate the results of studies measuring the location parameter with the default value determined by the Ministry of Environment in 2004. Later, research shows that the quality of the waters of the Pantai Kelapa Lima Kupang has begun to decline in the presence of contamination by sewage. Liquid waste is already affecting marine life that corals and mangroves, while the beauty of the sea coast, the liquid waste is already reducing the amount of oxygen for the oxidation process that takes coastal sea to the decomposition of waste into the sea, causing sedimentation affect water clarity sea shore. Therefore, there needs to be immediate action from the government to educate more people about the importance of maintaining the beauty of the beach, and helped make the disposal of liquid waste discharges in coastal areas to reduce the causes of liquid wastes into the coastal sea.
\end{abstract}

Keywords: coastal water quality; Kelapa Lima Kupang, sea water pollution; marine life

\begin{abstract}
Abstrak
Sumber daya pesisir seperti kehidupan biota laut dan panorama alam - dalam kategori wisata bahari adalah potensi - potensi yang dimiliki oleh Pantai Kelapa Lima Kupang. Walaupun demikian, terdapat permasalahan bahwa; perkembangan pembangunan, pemukiman, dan aktifitas perniagaan pesisir Pantai Kelapa Lima Kupang mengindikasikan adanya pencemaran oleh limbah cair terhadap perairan pantai ini. Permasalahan ini disesuaikan dengan standar yang Peraturan Menteri Lingkungan Hidup tahun 2014 nomor 51 dan tahun 2013 nomor 115 tentang standar baku mutu air laut. Metode yang digunakan adalah persamaan yang ditulis oleh Sumiotomo dan Nerow (1970) dalam Keputusan Menteri Negara Lingkungan Hidup Nomor : 115 Tahun 2003. Rumus yang ada digunakan untuk menghitung hasil ukur parameter dilokasi penelitian dengan nilai standar yang ditentukan oleh Menteri Lingkungan Hidup tahun 2004. Kemudian, hasil penelitian menunjukan bahwa kualitas perairan Pantai Kelapa Lima Kupang sudah mulai menurun dengan adanya pencemaran oleh limbah cair. Limbah cair sudah mempengaruhi kehidupan biota laut yaitu coral dan mangrove, sedangkan untuk keasrian air laut pantai, limbah cair sudah mengurangi jumlah oksigen untuk proses oksidasi yang dibutuhkan air laut pantai untuk proses penguraian limbah yang masuk kedalam air laut sehingga menimbulkan pengendapan yang berpengaruh pada kecerahan air laut pantai. Oleh karena itu perlu ada tindakan langsung dari pemerintah dengan memberikan penyuluhan kepada masyarakat mengenai pentingnya menjaga keasrian pantai, dan membantu membuat tempat pembuangan limbah cair buangan di pesisir pantai untuk mengurangi penyebab limbah cair yang masuk kedalam air laut pantai.
\end{abstract}

Kata Kunci: kualitas perairan pantai; Kelapa Lima Kupang; pencemaran air laut; biota laut

doi: https://doi.org/10.24843/blje.2019.v19.i02.p01

(C) 2019 by the authors; Content from this work may be used under the terms of the Creative Commons Attribution 3.0 licence. Any further distribution of this work must maintain attribution to the author(s) and the title of the work, journal citation and DOI. Published under licence by Udayana University, Indonesia. 


\section{Pendahuluan}

Kelurahan Kelapa Lima merupakan salah satu wilayah pesisir yang ada di Kota Kupang dengan memiliki garis pantai sekitar $\pm 2 \mathrm{Km}$ dan dapat diklasifikasikan sebagai pantai berpasir juga, juga sebagian pantai batu dan pantai bervegetasi. Pesisir pantai kelapa lima dipastikan memiliki nilai keindahan yang tinggi, sehingga memiliki potensi ekonomi yang cukup tinggi. Potensi ekonomi yang cukup tinggi yang dimiliki oleh kawasan Pesisir Kelapa Lima namun dihadapkan oleh ancaman pencemaran yang cukup tinggi pula. Berbagai macam aktifitas masyarakat di sekitar wilayah pesisir tersebut, menciptakan berbagai pembangunan yang sebagian besar didominasi oleh permukiman, perdagangan, hotel, restaurant, reklamasi, dan lain sebagainya. Pembangunan yang ada di sepanjang pesisir pantai Kelapa Lima menyebabkan permasalahan yaitu pencemaraan dan membahayakan sumberdaya kawasan pesisir dan laut karena bangunan-bangunan tersebut langsung membelakangi laut.

Pembangunan sepanjang pantai Kelapa Lima, menyebabkan keadaan sepanjang pesisir pantai Kelapa Lima dipenuhi oleh sampah dan menjadi tempat buangan air limbah dari pemukiman dan bangunan komersial lainnya. Hal ini dapat dijadikan indikator bahwa pengelolaan wilayah pesisir Kelapa Lima Kota Kupang, belum berwawasan lingkungan, belum menggunakan pendekatan kekinian yaitu water front city yang artinya wilayah perairan sebagai beranda depan kota. Kondisi saat ini menyebabkan potensi ekonomi yang dimiliki oleh kawasan tersebut belum dapat dimanfaatkan secara optimal, sehingga menyebabkan rendahnya kunjungan wisatawaan ke wilayah pantai dan kawasan pantai belum menjadi andalan ekonomi masyarakat di Kota Kupang. Oleh sebab itu, perlu adanya pengelolaan wilayah pesisir secara terpadu agar terhindar dari bahaya pencemaran. Dan pada penelitian ini, permasalahan yang dicari jalan keluarnya adalah untuk mengetahui sumber limbah, kualitas perairan, pengaruh limbah cair terhadap kualitas perairan di pantai Kelapa Lima Kota Kupang.

\section{Metode Penelitian}

\subsection{Waktu dan Lokasi}

Lokasi penelitian adalah berlokasi di Pantai Kelapa Lima Kota Kupang, sedangkan, waktu penelitian adalah pada bulan Agustus tahun 2016.

\subsection{Detail Waktu dan Lokasi Penelitian}

Lokasi penelitian ditentukan tiga stasiun sebagai tempat pengambilan sampel, yaitu : Stasiun I di belakang masjid, stasiun II di belakang pasar ikan, stasiun III di belakang hotel On The Rock Kelapa Lima, Kota Kupang. Sedangkan, waktu penelitian dimulai pada tanggal 11 Agustus 2016.

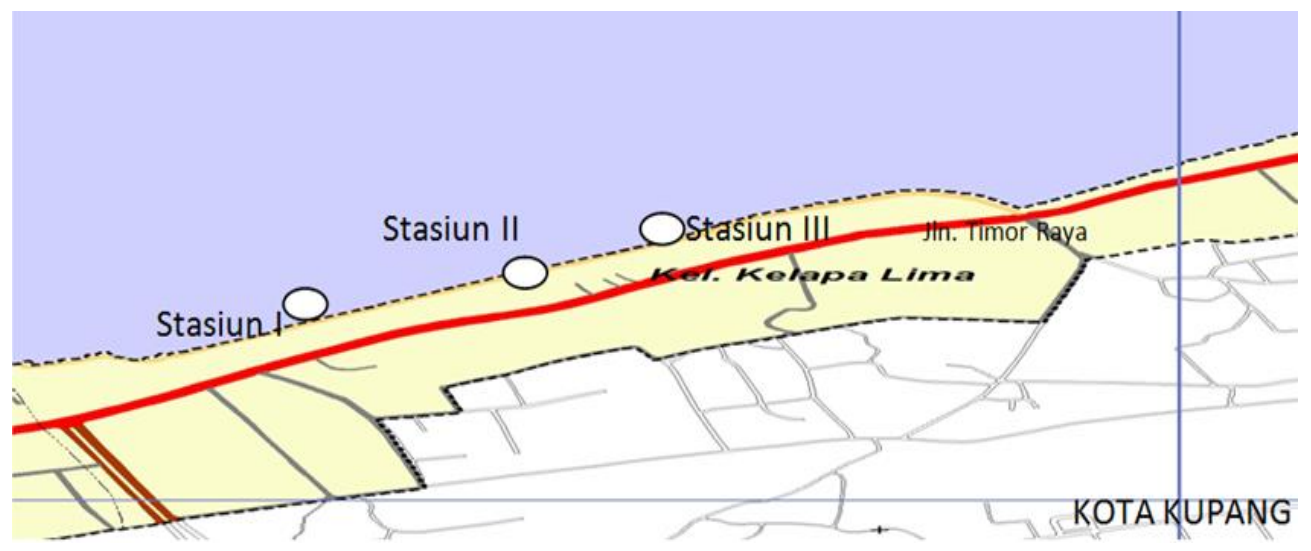

Gambar 1. Peta pantai kelapa lima Kota Kupang. 


\section{Hasil Dan Pembahasan}

Setelah dilakukan pengukuran di laboratorium, hasil pengukuran sampel parameter menunjukan bahwa perairan Pantai Kelapa Lima Kupang. Hal ini dibuktikan dengan perbandingan nilai hasil ukur dilapangan dengan standar baku mutu air laut yang ditentukan oleh Menteri Negara Lingkungan Hidup Nomor 51 tahun 2004 dan dihitung dan dikategorikan dengan menggunakan rumus baku sesuai Keputusan Menteri Negara Lingkungan Hidup Nomor 115 tahun 2003. Hasilnya tersaji dalam tabel, rumus, dan kategori berikut.

Tabel 1. Data lapangan, hasil hitung, dan kategori.

\begin{tabular}{|c|c|c|c|c|c|c|c|c|}
\hline \multirow[t]{4}{*}{ No } & \multirow{4}{*}{$\begin{array}{l}\text { Parameter } \\
\text { Pemeriksa } \\
\text { an }\end{array}$} & \multirow[t]{4}{*}{ Satuan } & \multicolumn{3}{|c|}{$\begin{array}{l}\text { Hasil dari } \\
\text { Lapangan }\end{array}$} & \multirow{4}{*}{$\begin{array}{c}\text { KepMenLH } \\
\text { Tahun } 2004 \\
\text { Tentang Baku } \\
\text { Mutu Air Laut }\end{array}$} & \multirow{4}{*}{$\begin{array}{l}\text { Nilai hitung } \\
\text { setelah mengg. } \\
\text { rumus }\end{array}$} & \multirow{4}{*}{$\begin{array}{c}\text { Kategori dari } \\
\text { KepMenLH Tahun } \\
2004\end{array}$} \\
\hline & & & Stas & Stas & Stas & & & \\
\hline & & & iun & iun & iun & & & \\
\hline & & & 1 & 2 & 3 & & & \\
\hline \multirow[t]{3}{*}{1} & BOD & $\mathrm{mg} / \mathrm{L}$ & 7,93 & 8,21 & 6,89 & 20 & Stasiun I: 0,39 & Kondisi baik \\
\hline & & & & & & & Stasiun II: 0,41 & Kondisi baik \\
\hline & & & & & & & Stasiun III: 0,34 & Kondisi baik \\
\hline \multirow[t]{3}{*}{2} & COD & $\mathrm{mg} / \mathrm{L}$ & 36 & 43 & 29 & Nilai P (untuk & Stasiun I: 5,28 & Tercemar sedang \\
\hline & & & & & & sebuah & Stasiun II: 5,672 & Tercemar sedang \\
\hline & & & & & & peruntukan) 5 & Stasiun III: 4,817 & Tercemar ringan \\
\hline \multirow[t]{9}{*}{3} & TSS & $\mathrm{mg} / \mathrm{L}$ & 73 & 89 & 28 & -Coral: 20 & Stasiun I: 3,8 & Tercemar ringan \\
\hline & & & & & & & Stasiun II: 4,24 & Tercemar ringan \\
\hline & & & & & & & Stasiun III: 1,73 & Tercemar ringan \\
\hline & & & & & & -Mangrove: 80 & Stasiun I: 0,91 & Kondisi baik \\
\hline & & & & & & & Stasiun II: 1,231 & Tercemar ringan \\
\hline & & & & & & & Stasiun III: 0,35 & Kondisi baik \\
\hline & & & & & & -Lamun: 20 & Stasiun I: 3,8 & Tercemar ringan \\
\hline & & & & & & & Stasiun II: 4,24 & Tercemar ringan \\
\hline & & & & & & & Stasiun III: 1,73 & Tercemar ringan \\
\hline \multirow[t]{3}{*}{4} & TDS & $\mathrm{mg} / \mathrm{L}$ & 3,92 & 3,95 & 3,87 & Nilai P (untuk & Stasiun I: 0,784 & Kondisi baik \\
\hline & & & & & & sebuah & Stasiun II: 0,79 & Kondisi baik \\
\hline & & & & & & peruntukan) 5 & Stasiun III: 0,76 & Kondisi baik \\
\hline \multirow[t]{3}{*}{5} & Kekeruha & NTU & 1,62 & 1,90 & 0,94 & $<5$ & Stasiun I: 0,324 & Kondisi baik \\
\hline & $\mathrm{n}$ & & & & & & Stasiun II: 0,38 & Kondisi baik \\
\hline & & & & & & & Stasiun III: 0,188 & Kondisi baik \\
\hline \multirow[t]{3}{*}{6} & Coliform & MPN/ & 240 & 240 & 21 & $1000(g)$ & Stasiun I: 0,24 & Kondisi baik \\
\hline & & 1000 & & & & & Stasiun II: 0,29 & Kondisi baik \\
\hline & & $\mathrm{ml}$ & & & & & Stasiun III: 0,021 & Kondisi baik \\
\hline
\end{tabular}




\subsection{Persamaan Matematika}

Persamaan matematika yang digunakan adalah rumus baku sesuai Keputusan Menteri Negara Lingkungan Hidup Nomor 115 tahun 2003 yang dirumuskan oleh Nemerow dan Sumitomo (1970).

$$
P I j=\frac{\sqrt{(C i / L i j) 2 R+(C i / L i j) 2 M}}{2}
$$

\subsection{Kategori Pencemaran}

Setelah data dihitung, lalu dikategorikan sehingga dapat menghasilkan kategori tingkat ketercemaran dengan menggunakan metode baku sesuai Keputusan Menteri Negara Lingkungan Hidup Nomor 115 tahun 2003 yaitu; ketika hasil yang didapatkan $1.0 \leq \mathrm{PIj} \leq 1,0$ maka dapat dikategorikan memenuhi baku mutu (kondisi baik), 1,0< $\mathrm{PIj} \leq 5,0$ maka hasil ini dikategorikan, tercemar ringan, 5,0 $<\mathrm{PIj} \leq 10$ maka hasil ini dikategorikan tercemar sedang, dan jika PIj> 10 maka hasil ini dikategorikan tercemar berat.

\section{Kesimpulan}

Limbah cair yang masuk ke dalam air laut pantai Kelapa Lima Kupang bersumber dari kegiatan kegiatan perniagaan di pesisir pantai, pasar ikan, dan pemukiman warga dibelakang masjid Kelapa Lima Kota Kupang. Hal ini menimbulkan pencemaran lewat analisa yang ada. Pada kualitas perairan dari faktor Fisika di lokasi penelitian. Ada beberapa parameter masih dalam kondisi baik, namun ada beberapa parameter - parameter Fisika seperti TSS untuk coral dan lamun stasiun I, II, dan III, dan mangrove hanya pada stasiun II, menunjukan bahwa kualitas perairan sudah mulai menurun. Hal ini ditunjukan dengan angka yang diperoleh. Dengan demikian, dapat dikatakan bahwa kualitas air akibat limbah cair sudah menurun dan mulai kehidupan coral, mangrove dan lamun. Selanjutnya, Pada kualitas kimia untuk perairan dilokasi penelitian, ditunjukan bahwa parameter kimia COD pada ketiga stasiun, menunjukan angka pencemaran sedang. Pencemaran COD pada lokasi ini berasal dari bahan buangan organik yang menghambat oksigen dalam proses oksidasi didalam perairan. Untuk kualitas perairan kimia dilokasi penelitian yang didalam analisis ini hanya memiliki satu parameter hitungan saja yaitu total coliform dan diketahui bahwa belum ada bakteri yang terlalu mengancam kualitas perairan pantai ini.

\section{Daftar Pustaka}

MNLH. (2001). Keputusan Menteri Negara Lingkungan Hidup Nomor 4 Tahun 2001 tentang Kriteria Baku Kerusakan Terumbu Karang. Jakarta-Indonesia: Menteri Negara Lingkungan Hidup.

MNLH. (2003). Keputusan Menteri Negara Lingkungan Hidup Nomor: 115 Tahun 2003 Tentang Pedoman Penentuan Status Mutu Air. Jakarta-Indonesia: Menteri Negara Lingkungan Hidup.

MNLH. (2004). Keputusan Menteri Negara Lingkungan Hidup Nomor: 51 Tahun 2004 Tentang Baku Mutu Air Laut. Jakarta-Indonesia: Menteri Negara Lingkungan Hidup

Nemerow, N. L., dan Sumitomo, H. (1970). Benefits of Water Quality Enhancement, Report No. 16110 $D A J$. prepared for the U.S. Environmental Protection Agency. Syracuse, NY: Syracuse University. 